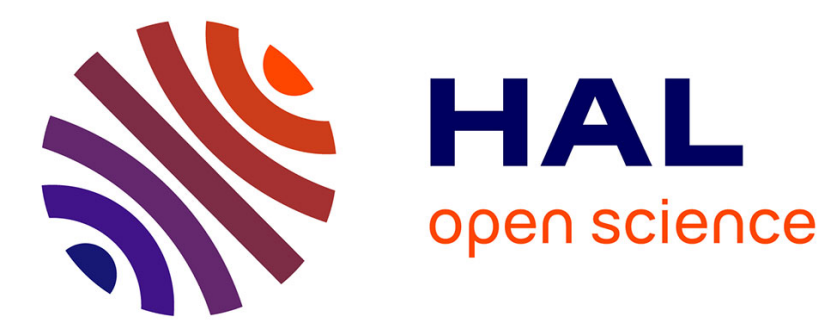

\title{
Mesoporous calcium phosphate using casein as a template: Application to bovine serum albumin sorption
}

Oberto Grangeiro da Silva, Marco Alves, Ieda Maria Garcia dos Santos, Maria Gardennia Fonseca, Maguy Jaber

\section{- To cite this version:}

Oberto Grangeiro da Silva, Marco Alves, Ieda Maria Garcia dos Santos, Maria Gardennia Fonseca, Maguy Jaber. Mesoporous calcium phosphate using casein as a template: Application to bovine serum albumin sorption. Colloids and Surfaces B: Biointerfaces, 2017, 158 (Octobre 2017), pp.480-487. hal01958215

\section{HAL Id: hal-01958215 \\ https: / hal.sorbonne-universite.fr/hal-01958215}

Submitted on 17 Dec 2018

HAL is a multi-disciplinary open access archive for the deposit and dissemination of scientific research documents, whether they are published or not. The documents may come from teaching and research institutions in France or abroad, or from public or private research centers.
L'archive ouverte pluridisciplinaire HAL, est destinée au dépôt et à la diffusion de documents scientifiques de niveau recherche, publiés ou non, émanant des établissements d'enseignement et de recherche français ou étrangers, des laboratoires publics ou privés. 


\section{Mesoporous calcium phosphate using casein as a template:}

\section{application to bovine serum albumin sorption}

Oberto Grangeiro da Silva ${ }^{\mathrm{a}}$, Marco Marciel Alves ${ }^{\mathrm{a}}$, Ieda Maria Garcia dos Santos ${ }^{\mathrm{b}}$, Maria Gardennia Fonseca $^{b^{*}}$, Maguy Jaber ${ }^{\mathrm{c}}$

${ }^{a}$ Departamento de Química, Instituto Federal de Educação, Ciência e Tecnologia do Rio Grande do Norte.

${ }^{b}$ LACOM, Universidade Federal da Paraíba, Campus 1, CEP 58059-900, João Pessoa, PB, Brazil.

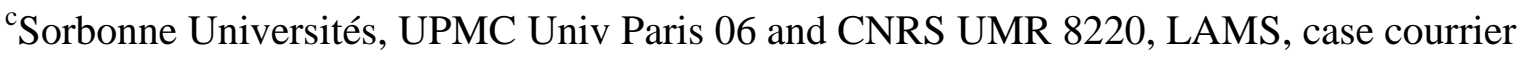
225, UPMC 4 Pl. Jussieu, 75252 PARIS CEDEX 05

\section{AUTHOR INFORMATION}

\section{Corresponding Author}

*Email: mgardennia@quimica.ufpb.br 


\section{ABSTRACT}

Mesoporous hydroxyapatites were synthesized at room temperature using casein as a template, and key experimental factors, such as casein concentration, $\mathrm{pH}$ and extraction of casein in the final solids by washing and thermal treatment, were systematically investigated. The X-Ray Diffraction (XRD) patterns confirmed the synthesis of well-crystallized hydroxyapatite. The $\mathrm{N}_{2}$ adsorption/desorption isotherms were in agreement with the formation of mesoporous hydroxyapatite with a maximum surface area of $106 \mathrm{~m}^{2} \mathrm{~g}^{-1}$. Infrared spectroscopy and thermogravimetry analysis were performed to investigate the extraction of casein in water in the post-synthesis stage. Pure mesoporous hydroxyapatite exhibited good BSA adsorption capacity higher than the one obtained for conventional hydroxyapatite.

KEYWORDS Hydroxyapatite; mesoporous solid; calcium phosphate; casein; protein sorption 


\section{Introduction}

Among calcium phosphates, hydroxyapatite (Hap) is the principal inorganic component of hard tissues (bones and teeth) in humans and animals and represents approximately $70 \%$ of the inorganic mass $[1,2]$. Pure Hap is a biocompatible material that can be implanted or placed in contact with tissues or organs of the human body and does not cause any adverse reaction due to rejection or contamination [3, 4]. However for synthetic Hap, its biocompatibility depends of the conditions of syntheses such as use of organic solvent or some organic templates could decrease the biocompatibility. Hap exhibits a positive response in terms of adhesion and proliferation of different cell types when used as implant [5]. Numerous strategies have been investigated to obtain macrostructured calcium phosphate with different morphologies, such as films and beads $[6,7]$, for use as a stationary phase in chromatography for the separation and purification of proteins and enzymes [8-10], a support for controlled drug release [11-15], a catalyst for the synthesis of biofuels and other organic derivates [16, 17], an adsorbent to remove cations or anions from solution [18-20], a sensor for humidity and $\mathrm{CO}_{2}$ [21] or a macroporous structure for natural bone growth [22]. Hap with a high surface area and large pore volume are typically required for use as adsorbents. In addition, the pore size control increases the potential for the use of calcium phosphate for selective nanometer-sized biomolecule adsorption [23]. In general, ordered mesoporous pore arrangement and narrow pore distribution are not observed in conventional calcium phosphate [25]. Some studies demonstrated that nanosized Hap has a high surface functional properties, resulting in better cell adhesion and cell-matrix interactions [2, 24].

However, few studies on mesoporous hydroxyapatite have been reported because calcium and phosphates ions have a strong tendency to interact with each other even in the presence of surfactant molecules [26]. Therefore, the preparation of pure mesoporous calcium phosphate without other calcium phosphate phases, such as brushita, monetite, tricalcium phosphate and apatite, is challenging [27].

According to Schmidt and co-authors [28], the three main challenges in the synthesis of mesoporous calcium phosphates are (1) the production of nano- or microsize particles, (2) the formation of ordered mesopores and (3) the generation of a stable material with a high surface area after template removal. The last point is important because the surfactant removal procedure typically involves thermal treatment or washing with acidic solutions that destroy the mesostructure of the calcium phosphates, which results in disordered porous materials with low surface areas. However, some studies have reported the synthesis of 
mesostructured calcium phosphates with specific surface areas in the range of 20-60 $\mathrm{m}^{2} \mathrm{~g}^{-1}$, and these materials were prepared via soft template routes with anionic [29], cationic [28, 30, 31] and neutral surfactants [32] or co-polymers [33] and hard template routes [34]. However, due to processing problems, a reliable method for the synthesis of mesoporous calcium phosphate with a high surface area has not been established [29] despite the fact that in nature, biomineralization of calcium phosphate in the presence of biosurfactants (i.e., lipids, sugar, proteins and amino acids) commonly occurs in biological systems [28]. An example of calcium phosphate biomineralization is the interaction of colloidal calcium phosphate fragments with casein in milk. Casein is an amphiphilic phosphoprotein, which has hydrophobic and hydrophilic moieties [35] with a high affinity for calcium phosphate [36]. The typical composition (wt) of bovine casein is approximately 49\% $\alpha$-casein (199, and 207 amino acids for $\alpha \mathrm{S} 1(22-23.7 \mathrm{KDa})$ and $\alpha \mathrm{S} 2$-casein $(\sim 25 \mathrm{kDa})), 37 \% \beta$-casein $(209$ amino acids, $\sim 24 \mathrm{kDa}$ ) and 14\% k-casein (169 amino acids, $\sim 19 \mathrm{KDa}$ ) [37]. In aqueous solutions, casein forms micelles with diameters ranging from 90 to $140 \mathrm{~nm}$ ) [38, 39]. The micelles consist of sub-micelles, which are approximately $20 \mathrm{~nm}$ in size, that contain 20-25 casein molecules [40]. At highly alkaline $\mathrm{pH}$ values, such as that in cement pore solutions, casein micelles disintegrate into sub-micelles and single proteins.

Casein has been used in some inorganic studies. In this case, Ca-Al layered double hydroxides/casein hybrids were synthesized with whole protein and pure $\alpha$ - and $\beta$-casein. The intercalation of the $\beta$-form was easier than that of the $\alpha$-form [41].

A $\beta$-casein-based drug delivery system was proposed as an efficient nanocarrier for oral celecoxib delivery, which is an anticancer drug as well as an anti-inflammatory hydrophobic drug for the treatment of rheumatoid arthritis and osteoarthritis [42].

To the best of our knowledge, only two studies have described the use of casein for the synthesis of hydroxyapatite $[43,44]$. In the first study, aqueous micelles of the multi-casein calcium phosphate complex were treated at $60^{\circ} \mathrm{C}$ and a $\mathrm{pH}$ of 7 for several months [43]. The partial dissociation of the micelles into $12 \mathrm{~nm}$ sized amorphous calcium phosphate (ACP)/protein nanoparticles occurred within a period of 14 days, and crystallization of the ACP nanoclusters into bundles of hydroxyapatite (Hap) nanofilaments was not observed prior to 12 weeks. The Hap nanofilaments were specifically formed within the partially disrupted protein micelles, suggesting a micelle-mediated pathway for mesoscale crystallization.

In the second study [44], nanorod-assembled porous microspheres of Hap/casein were prepared using adenosine 5'-triphosphate disodium salt $\left(\mathrm{Na}_{2} \mathrm{ATP}\right)$ as a phosphorus source, 
calcium chloride as a calcium source in the presence of casein sodium salt as a template using the hydrothermal method.

Therefore, casein can be employed as a promising biosurfactant in the synthesis of calcium phosphate. The current study aimed to synthesize hydroxyapatite with controlled porosity using casein as a template and to evaluate the key experimental parameters in this process, such as the concentration of the surfactant, the $\mathrm{pH}$, the temperature, the heating rate during calcination and surfactant removal by washing with water. The mesoporous solids were applied to BSA sorption. The retention of proteins and other biomolecules on the solid/liquid interface may lead to useful applications in engineering, technology, biology and wastewater treatment [45-49].

\section{Materials and methods}

\subsection{Preparation of pure Hap}

HAP was synthesized using ammonium phosphate $\left(\left(\mathrm{NH}_{4}\right)_{2} \mathrm{HPO}_{4}-\mathrm{QEEL}, 99 \%\right)$ and calcium chloride $\left(\mathrm{CaCl}_{2} \cdot 2 \mathrm{H}_{2} \mathrm{O}-\mathrm{CROSS}, 99 \%\right)$ in aqueous solutions containing $0.033 \mathrm{~mol}$ and $0.056 \mathrm{~mol}$ of each salt, respectively, and a Ca:P ratio of 1.67. Deionized water was used in all preparations.

Casein from bovine milk (REAGEN) was employed. Any purification or isolation of the casein was performed prior to use. First, $250 \mathrm{~cm}^{3}$ of 1 and $5 \mathrm{mg} \mathrm{cm}^{-3}$ casein solutions were prepared in two buffer solutions at three $\mathrm{pH}$ values as follows: 7.0 and 8.0 , imidazole $/ \mathrm{HCl}$ (MERK/VETEC, 99\%) and 11.0, $\mathrm{NH}_{4} \mathrm{Cl} / \mathrm{NH}_{4} \mathrm{OH}$ (MERK/VETEC, 99\%).

$250 \mathrm{~cm}^{3}$ of the casein solution was mechanically stirred at $1400 \mathrm{rpm}$ for $1 \mathrm{~h}$ at room temperature to form a white suspension. Then, the agitation was adjusted to $200 \mathrm{rpm}$, and 250 $\mathrm{cm}^{3}$ of both salt solutions were added dropwise at a rate of $2 \mathrm{~cm}^{3} \mathrm{~min}^{-1}$. The white precipitate was aged at room temperature for $24 \mathrm{~h}$. The suspension was filtered, and the obtained solid was divided in two parts. The first part was washed with water for 5 days until a negative chloride test was achieved, and the second part was used without any washing. The two solids were dried at $373 \mathrm{~K}$ for $24 \mathrm{~h}$. Then, the washed HAP samples were calcined at 573, 773 and $873 \mathrm{~K}$ for $6 \mathrm{~h}$ under an $\mathrm{O}_{2}$ atmosphere at a heating rate of 2,10 and $25 \mathrm{~K} \mathrm{~min}^{-1}$. The solids are referred as HapCAS $\mathrm{x} / \mathrm{y}$, where $x$ is the casein concentration and $\mathrm{y}$ is the $\mathrm{pH}$. The unwashed, washed and calcined samples were characterized. 


\subsection{Analytical techniques}

The X-ray powder diffraction (XRD) patterns were recorded at room temperature on a Shimadzu diffractometer model XD3A using $\mathrm{CuK} \alpha$ radiation $(\lambda=0.154 \mathrm{~nm})$ at $30 \mathrm{kV}$ and 20 $\mathrm{mA}$ at a rate scan of $0.03^{\circ} \mathrm{seg}^{-1}$ for a $2 \theta$ range of 5 to 60 degrees. The porosity of the samples was determined by nitrogen adsorption-desorption experiments at $77 \mathrm{~K}$ using an ASAP 2010 Micromeritics automated gas adsorption system. Prior to analysis, the samples were outgassed under vacuum at $473 \mathrm{~K}$ for $2 \mathrm{~h}$. The specific surface area was determined using the Brunauer-Emmett-Teller (BET) equation. The volume and pore size distribution were obtained using the Barrett-Joyner-Halenda (BJH) method. The Fourier transform infrared (FTIR) spectra were recorded at room temperature on a MB-Series FTIR Bomem spectrophotometer with the samples in $\mathrm{KBr}$ pellets at a sample concentration of $1 \%(\mathrm{w} / \mathrm{w})$. Each spectrum was obtained by averaging 30 consecutive scans that were collected in a range from 4000 to $400 \mathrm{~cm}^{-1}$ at a resolution of $4 \mathrm{~cm}^{-1}$. The quantity of casein on the solids was based on the nitrogen content that was determined via CHN Elemental analysis on a PerkinElmer elemental analyzer model PE 2400. The thermogravimetric curves were obtained on a DuPont instrument model 1090 in a nitrogen atmosphere at a flow rate of $50 \mathrm{~cm}^{3} \mathrm{~min}^{-1}$ and a heating rate of $4.71 \mathrm{~K} \mathrm{~s}^{-1}$ with temperatures ranging from 300 to $1200 \mathrm{~K}$. The micrographs were recorded on a JEOL JEM-100 CXII apparatus operating at $200 \mathrm{keV}$. Samples in the form of bulk powders were suspended in ethanol and then deposited on 400 mesh copper grids covered with an ultrathin carbon membrane of $2-3 \mathrm{~nm}$ thickness.

\subsection{BSA sorption}

The kinetic study for the BSA adsorption on micro and mesoporous Hap was conducted using various reaction times. $1000 \mathrm{mg} \mathrm{dm}^{-3}$ of BSA solution was prepared in a phosphate saline buffer $\left(\left(0.067 \mathrm{~mol} \mathrm{~L}^{-1} \mathrm{KH}_{2} \mathrm{PO}_{4} / 0.067 \mathrm{~mol} \mathrm{dm}{ }^{-3} \mathrm{Na}_{2} \mathrm{HPO}_{4} .2 \mathrm{H}_{2} \mathrm{O}\right)\right.$ at a $\mathrm{pH}$ of 7.2. $50 \mathrm{mg}$ samples of the solid were suspended in $25 \mathrm{~cm}^{3}$ of the BSA solution, and the solid/BSA suspensions were placed in a thermostated bath with an orbital agitation of 130 rpm at $298 \pm 1 \mathrm{~K}$ for 0 to 120 minutes. At pre-determined intervals, the samples were centrifuged at $4000 \mathrm{rpm}$ for 15 minutes, and the BSA concentration remaining in the solution after each time interval was determined using a HP Ultraviolet-Visible spectrophotometer model 8453 at $595 \mathrm{~nm}$ according to the Bradford method [50].

The quantity of adsorbed protein on the solid was determined as follows: 


$$
q=\frac{(C i-C e)}{m} V
$$

where $\mathrm{Ci}$ and $\mathrm{Ce}$ are the initial and equilibrium concentrations of BSA in the solution, respectively, $\mathrm{V}$ is the volume of the solution and $\mathrm{m}$ is the mass of HAP.

To study the adsorption isotherms of BSA on HAP, $25.0 \mathrm{~mL}$ of the protein solution at concentrations ranging from 50 to $500 \mathrm{mg} \mathrm{dm}^{-3}$ were reacted with $50 \mathrm{mg}$ of the solid, and the suspensions were placed in a thermostated bath with stirring at $298 \mathrm{~K}$ for the time established in the kinetic study. After equilibrium, the samples were centrifuged, the supernatant was removed, and the BSA concentrations were determined as previously described.

A control experiment was performed using Hap and saline solutions at the same conditions. The concentration of ions in solution was monitored by by inductively coupled plasma - optical emission spectroscopy (ICP OES, Radial) using an Arco spectrometer from Spectro. Any variation in the $\mathrm{Na}^{+}$and $\mathrm{K}^{+}$concentrations were observed comparing to the solutions before and after equilibrium. Therefore, any influence of saline solution on Hap was observed.

\section{Results and discussion}

\subsection{Effect of thermal treatment}

The XRD patterns of the non-calcined and calcined solids at $573 \mathrm{~K}$ are shown in Figure 1 (for samples calcined at 773 and $873 \mathrm{~K}$ see Supplementary material Figure SM-1). Well-crystalized Hap (indexed according to JCPDS 09-0432) was obtained at different pH and two casein concentrations. The thermal treatment did not alter drastically the crystallinity eventhough the peak at $10^{\circ}(100)$ for calcined samples is broader. It has been reported that the (100) reflection is responsible for the interaction with biomolecules [51]. The characteristic reflections associated to (211), (112) and (300) of Hap were maintained. 

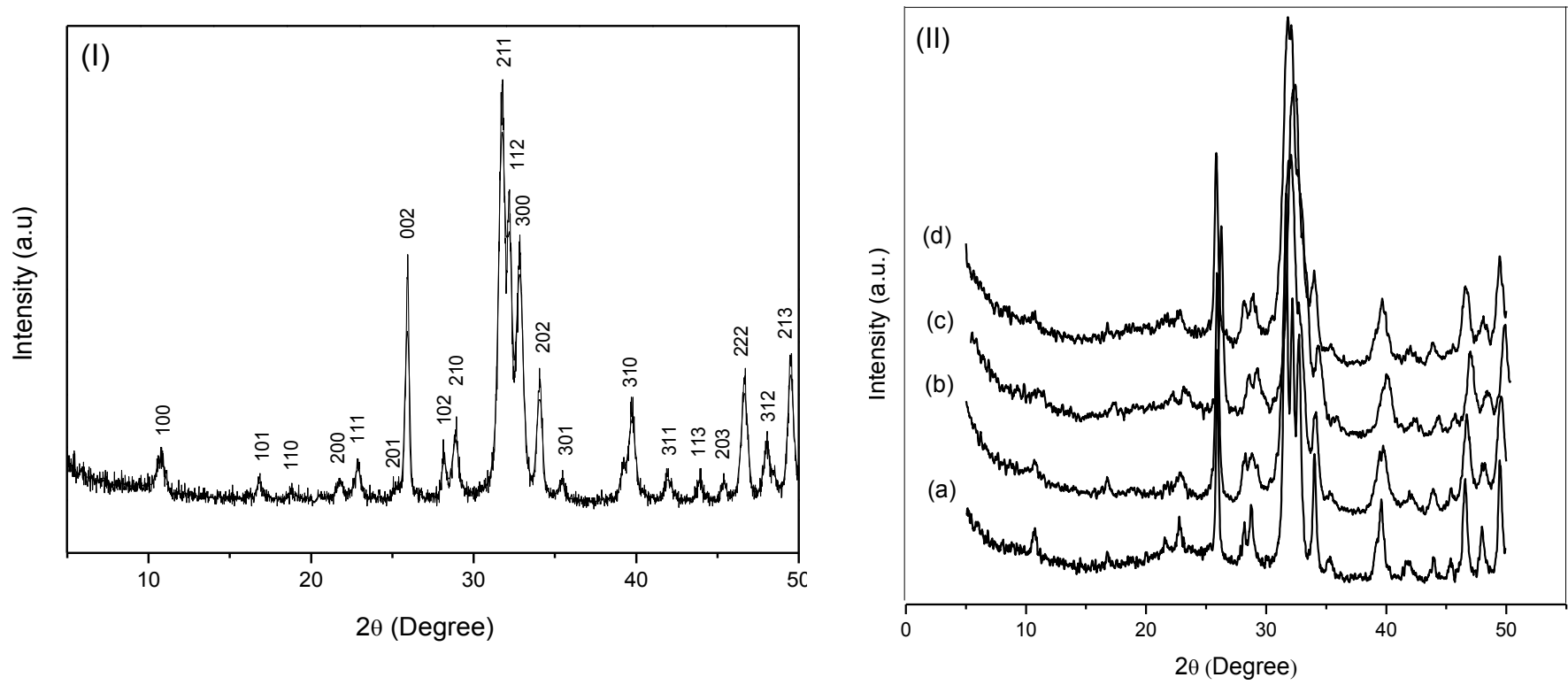

Figure 1. XRD patterns of (I) conventional hydroxyapatite obtained without casein; and (a) washed and non-calcined hydroxyapatite $\mathrm{HapCAS}_{1.0 / 7.0}$ and $\mathrm{HapCAS}_{1.0 / 7.0}$ calcined at (II) 573 $\mathrm{K}$ using a heating rate $\left(\mathrm{K} \mathrm{min}^{-1}\right)$ of (b) 2, (c) 10 and (d) 25 .

The textural properties based on the adsorption/desorption nitrogen measurements are listed in Tables 1 and $\mathbf{2}$ for the solids obtained under different conditions. The solids with higher specific surface areas and smaller pores diameters were obtained at $573 \mathrm{~K}$ and a heating rate of $10 \mathrm{~K} \mathrm{~min}^{-1}$ (see Table 1 and Supplementary material Figure SM-2). These conditions ( $573 \mathrm{~K}$ and a heating rate of $10 \mathrm{~K} \mathrm{~min}^{-1}$ ) were used to obtain the other solids, and the textural properties are presented in Table 2. All of the synthesized materials had a surface area of 55-106 $\mathrm{m}^{2} \mathrm{~g}^{-1}$. The values are higher than those reported for mesoporous calcium phosphates $[52,53]$ as well as for conventional hydroxyapatite, which have a surface area of $20 \mathrm{~m}^{2} \mathrm{~g}^{-1}$ [54]. The data suggested that calcination at higher temperatures does not affect the surface area. For the non-calcined Hap (washed samples), the surface area was the same than the one observed for the calcined samples, suggesting the extraction of casein by washing. The $\mathrm{N}_{2}$ isotherms for the calcined Hap at $573 \mathrm{~K}$ with a heating rate of $10 \mathrm{~K} \mathrm{~min}^{-1}$ were type IV (Figure 2 and Supplementary material Figure SM-3), which is 
characteristic of mesoporous solids, with $\mathrm{H} 3$ hysteresis. The $\mathrm{P} / \mathrm{P}_{0}$ position with an inflection at $0.70-1.0$ confirmed the structural characteristic of the pores. Two distinct regions in the $\mathrm{N}_{2}$ isotherms were observed (Figure 2). The initial $\mathrm{N}_{2}$ adsorption occurred at a low pressure followed by a multilayer adsorption until the appearance of the inflection point at a $\mathrm{P} / \mathrm{P}_{0}$ of 0.7. Then, the quantity of adsorbed gas increased abruptly with a slight increase in the pressure due to $\mathrm{N}_{2}$ condensation in the primary mesopores. The solid HapCAS $\mathrm{S}_{5.0 / 11.0}$ (Figure 2c) displayed a third region in the $\mathrm{N}_{2}$ isotherm. Above a $\mathrm{P} / \mathrm{P}_{0}$ of 0.9 , the curves were asymptotic, which is characteristic of capillary condensation in secondary mesopores.
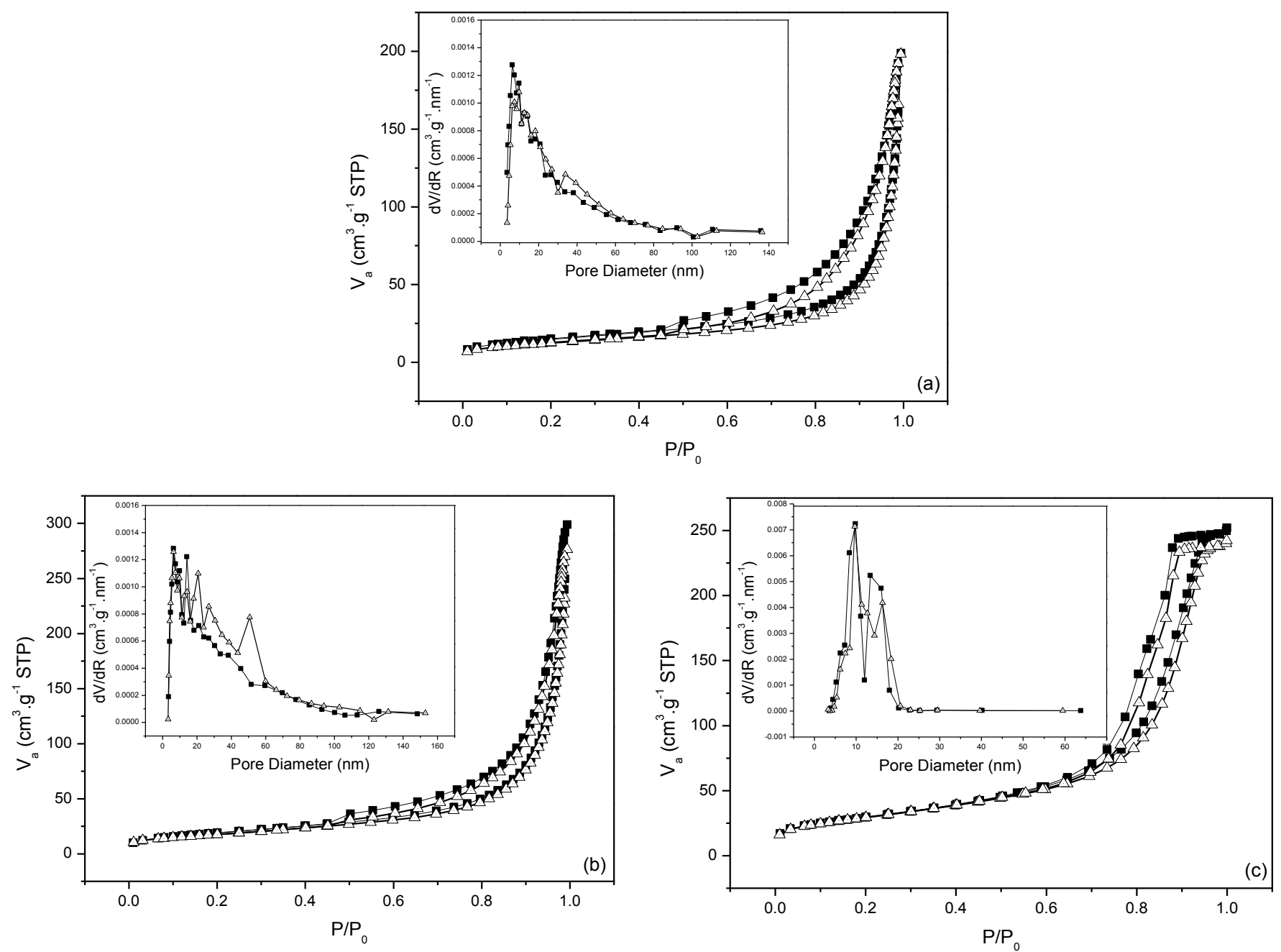

Figure 2. Nitrogen adsorption/desorption isotherms of (a) $\operatorname{HapCAS}_{5.0 / 7.0}$, (b) HapCAS $\mathrm{H}_{5.0 / 8.0}$ and (c) HapCAS ${ }_{5.0 / 11.0}$ calcined at $573 \mathrm{~K}$ with a heating rate of $10 \mathrm{~K} \mathrm{~min}^{-1}(\Delta)$. Non-calcined

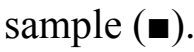


Table 1 - Textural properties for HAP synthesized with $1 \mathrm{mg} \mathrm{L}^{-1}$ casein at a $\mathrm{pH}$ of 7.0 before and after thermal treatment with three heating rates in an oxygen atmosphere.

\begin{tabular}{ccccc}
\hline $\begin{array}{c}\text { Temperature } \\
(\mathrm{K})\end{array}$ & $\begin{array}{c}\text { Heating rate } \\
\left(\mathrm{K} \mathrm{min}^{-1}\right)\end{array}$ & $\begin{array}{c}\mathrm{S}_{\mathrm{BET}} \\
\left(\mathrm{m}^{2} \mathrm{~g}^{-1}\right)\end{array}$ & $\begin{array}{c}\mathrm{Vp} \\
\left(\mathrm{cm}^{3} \mathrm{~g}^{-1}\right)\end{array}$ & $\begin{array}{c}\mathrm{Dp} \\
(\mathrm{nm})\end{array}$ \\
\hline- & - & 53 & 0.278 & 17.90 \\
573 & 2 & 52 & 0.285 & 16.00 \\
& 10 & 54 & 0.309 & 16.52 \\
& 25 & 52 & 0.269 & 16.00 \\
773 & 2 & 45 & 0.261 & 20.21 \\
& 10 & 46 & 0.273 & 20.55 \\
& 25 & 50 & 0.278 & 18.00 \\
& 2 & 42 & 0.284 & 25.06 \\
& 10 & 45 & 0.289 & 23.23 \\
& 25 & 42 & 0.262 & 23.72
\end{tabular}

$\mathrm{S}_{\mathrm{BET}}=$ specific surface area, $\mathrm{Vp}=$ pore volume, $\mathrm{Dp}=$ pore diameter. 
Table 2 - Textural properties for HAP synthesized at casein concentrations of 1 and $5 \mathrm{mg} \mathrm{L}^{-1}$ before and after thermal treatment in an oxygen atmosphere at $573 \mathrm{~K}$ and $10 \mathrm{~K} \mathrm{~min}^{-1}$.

\begin{tabular}{|c|c|c|c|c|}
\hline $\begin{array}{l}\text { Casein concentration } \\
\qquad\left(\mathrm{mg} \mathrm{L}^{-1}\right)\end{array}$ & $\mathrm{pH}$ & $\begin{array}{c}\mathrm{S}_{\mathrm{BET}} \\
\left(\mathrm{m}^{2} / \mathrm{g}\right)\end{array}$ & $\begin{array}{c}V p \\
\left(\mathrm{~cm}^{3} / \mathrm{g}\right)\end{array}$ & $\begin{array}{c}\mathrm{Dp} \\
(\mathrm{nm})\end{array}$ \\
\hline \multirow[t]{6}{*}{1} & 7.0 & $53^{*}$ & $0.278^{*}$ & $17.90^{*}$ \\
\hline & & 54 & 0.309 & 16.52 \\
\hline & 8.0 & $67^{*}$ & 0.189* & 9.98* \\
\hline & & 69 & 0.180 & 13.73 \\
\hline & 11.0 & $82 *$ & $0.267^{*}$ & $13.10 *$ \\
\hline & & 83 & 0.237 & 14.70 \\
\hline \multirow[t]{6}{*}{5} & 7.0 & $67^{*}$ & $0.215^{*}$ & $15.90 *$ \\
\hline & & 68 & 0.169 & 15.42 \\
\hline & 8.0 & $84^{*}$ & 0.193 & 10.05 \\
\hline & & 86 & 0.185 & 10.62 \\
\hline & 11.0 & $106 *$ & $0.370^{*}$ & $12.72^{*}$ \\
\hline & & 107 & 0.384 & 12.95 \\
\hline
\end{tabular}

The well-defined form in the adsorption/desorption branches indicate uniform pore diameters for the materials, as shown in the distribution curves (Figure 2 and Supplementary material Figure SM-3), with a very narrow size in the range of $15-20 \mathrm{~nm}$ for all of the solids.

TEM experiments were performed on $\operatorname{HapCAS}_{5.0 / 11.0}$ (Figure 3). Microporous Hap sample do not exhibit any organized porosity. The sample possesses hexagonal morphology but without any structural porosity, as demonstrated by the nitrogen adsorption-desorption measurements. After calcination of the solid at $573 \mathrm{~K}$, black and white stripes with a separation distance varying between 1.2 and $1.8 \mathrm{~nm}$ were observed in the images of the sample. 


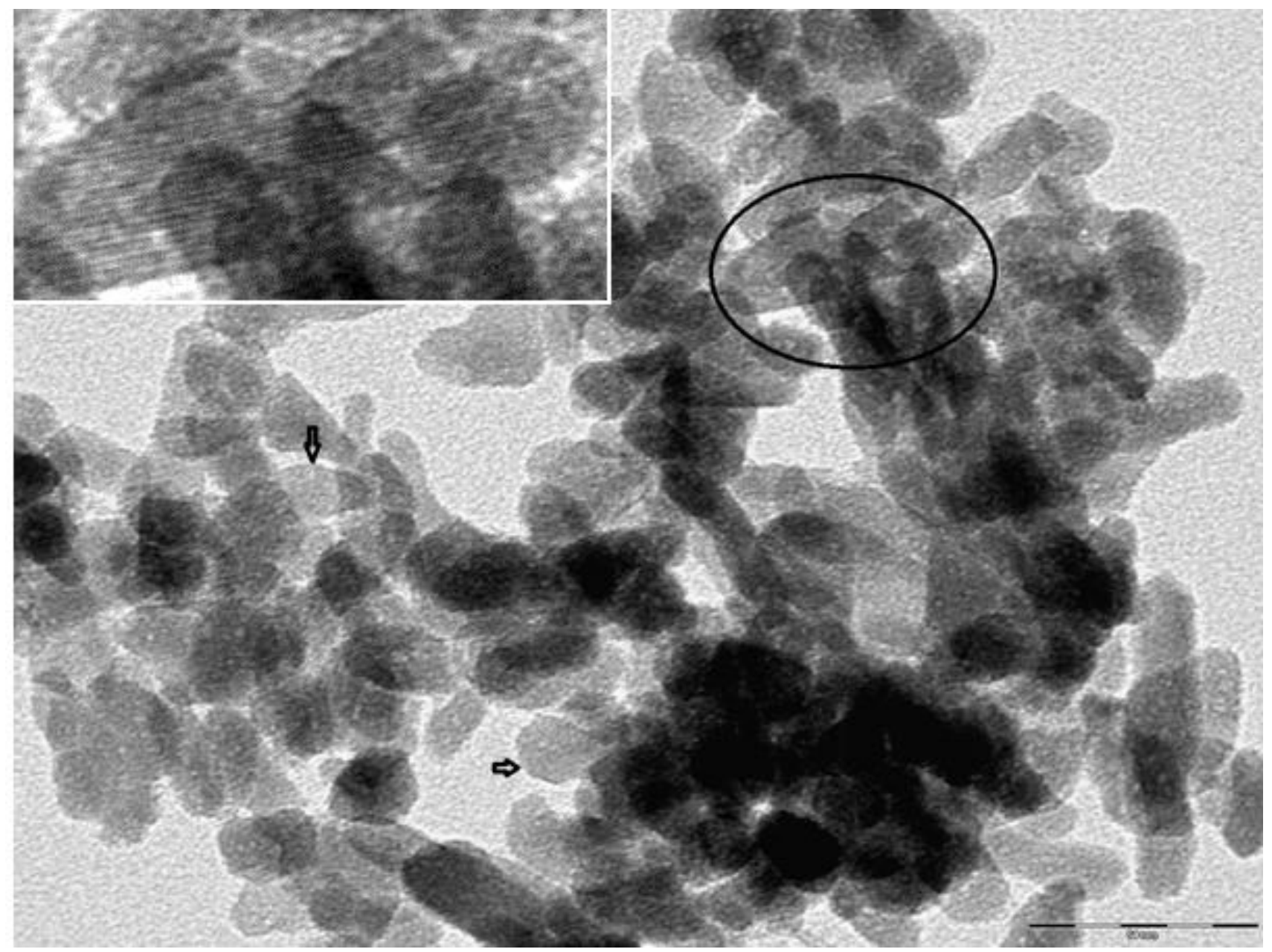

Figure 3. TEM image of the HapCAS ${ }_{5.0 / 11.0}$ calcined at $573 \mathrm{~K}$ with a heating rate of $10 \mathrm{~K} \mathrm{~min}$ 1 .

The infrared spectra of the calcined and non-calcined Hap samples (Supplementary material Figure SM-4) contained a band at $3500 \mathrm{~cm}^{-1}$, which was assigned to the $\mathrm{OH}$ stretching vibrations of adsorbed water and the phosphate group. The $\mathrm{OH}$ bending vibration was observed at $1620 \mathrm{~cm}^{-1}$. The characteristic bands associated with phosphate vibrations were observed at 1100, 1000 and $950 \mathrm{~cm}^{-1}$ due to asymmetric deformation of $\mathrm{PO}_{4}{ }^{3-}$ and 850 $\mathrm{cm}^{-1}$ due to $\mathrm{P}-\mathrm{O}(\mathrm{H})$ stretching in $\mathrm{HPO}_{4}{ }^{2-}[55,56]$. The bands located at 600 and $550 \mathrm{~cm}^{-1}$ were assigned to the $\mathrm{P}-\mathrm{O}$ and $\mathrm{P}-\mathrm{O}(\mathrm{H})$ asymmetric deformations of $\mathrm{PO}_{4}{ }^{3-}$ and $\mathrm{HPO}_{4}{ }^{2-}$, respectively $[5]$.

Some differences in the spectra were observed for the calcined samples (Figure SM4). In addition to the characteristic bands of the inorganic phase, low intensity bands were 
observed at 2938 and $2853 \mathrm{~cm}^{-1}$, which correspond to C-H asymmetrical and symmetrical stretching of methylene groups, respectively. In addition, two medium bands located at 1465 and $1421 \mathrm{~cm}^{-1}$ were due to $\mathrm{CH}_{2}$ scissoring and $\mathrm{C}-\mathrm{OH}$ in plan bendings, respectively [57], and the $\mathrm{NH}_{2}$ wagging mode at $871 \mathrm{~cm}^{-1}$ indicating the presence of casein in the phosphate. These three last vibrations were more pronounced in the calcined solids (at 572 and $773 \mathrm{~K}$ ), indicating that the casein was not fully extracted. The bands in the non-calcined solids were more intense. The $\mathrm{NH}_{2}$ wagging band was not observed in the solids calcined at $873 \mathrm{~K}$, but very low $\mathrm{C}-\mathrm{H}$ stretchings and $\mathrm{CH}_{2}$ were maintained, suggesting the remaining casein in this sample.

The CHN results (Supplementary material Table SM-1) confirmed the presence of a high organic content in the samples prior to washing and calcination. The thermal treatment removed nearly all of the casein, as shown in Table 3, i.e. $93 \%$ for $873 \mathrm{~K}$. The low $\mathrm{CN}$ content in the washed and non-calcined samples suggested that $64 \%$ of the casein was removed with intensive washing. This result is important because template removal is a crucial part in the synthesis of mesoporous Hap.

The TG curves of the non-calcined and calcined HapCAS H.0/7.0 $_{\text {samples }}$ (Supplementary material Figure SM-5 and Table SM-2) was used to determine the organic matter content, and the results are in agreement with the CHN data, confirming that the casein was nearly removed by washing. The amount of remaining casein in the solids after calcination is very small and did not alter the porosity characteristics of the materials, as previously discussed. All of the TG curves have the same general behavior with three weight loss steps due to thermal decomposition of the inorganic skeleton. The TG(DTG) curves of casein (see Supplementary material Figure SM-6) show its decomposition between 465-850 $\mathrm{K}[58]$.

For mesoporous Hap samples, TG curves showed the first event occurring at 300-498 K due to the loss of physisorbed water from the surface and pores of the material. The second step at 498-1073 K was due to the thermal decomposition of casein, which occurs above 465 $\mathrm{K}$ [57]. A third loss step was observed above $1073 \mathrm{~K}$ and is related to the decomposition of hydroxyapatite, as described in the following equation $[59,60]$ :

$$
\mathrm{Ca}_{10}\left(\mathrm{PO}_{4}\right)_{6}(\mathrm{OH})_{2} \rightarrow \mathrm{Ca}_{10}\left(\mathrm{PO}_{4}\right)_{6}(\mathrm{OH})_{2-2 \mathrm{x}} \mathrm{O}_{\mathrm{x}}+x \mathrm{H}_{2} \mathrm{O}
$$

(above $1073 \mathrm{~K}$ )

The TG curves exhibited some differences for the HapCAS $\mathrm{S}_{1.0 / 7.0}$ mesoporous solids as a function of the calcination temperature. The amount of mass lost for all of the solid was nearly the same and independent of the calcination temperature, which confirmed the 
elemental analysis (Table 3). However, based on a quantitative evaluation of the weight loss in the second step (thermal decomposition of casein), a gradual decrease in the weight loss was observed for the solids calcined at higher temperatures. Therefore, the casein was not completely removed from the HAP after calcination at 573 and $773 \mathrm{~K}$. These data are in concordance with $\mathrm{CHN}$ results.

Table 3 - CHN data of the HAP synthesized at a pH of 7.0 and a casein concentration of 1.0 $\mathrm{mg} \mathrm{L}^{-1}$ before and after washing and calcination at different temperatures $(\mathrm{T})$.

*washed and non-calcined sample.

\begin{tabular}{|c|c|c|c|c|c|}
\hline $\mathrm{T}$ & $\begin{array}{c}\text { Heating } \\
\text { rate } \\
\left(\mathrm{K} \mathrm{min}^{-1}\right)\end{array}$ & $\mathrm{C}(\%)$ & $\mathrm{H}(\%)$ & $\mathrm{N}(\%)$ & \multicolumn{2}{c|}{$\begin{array}{c}\text { Casein } \\
\text { removal (\%) }\end{array}$} \\
\hline- & - & $0.78 \pm 0.2^{*}$ & $0.54 \pm 0.01^{*}$ & $0.16 \pm 0.02^{*}$ & 64 \\
\hline 573 & 2 & $0.68 \pm 0.02$ & $0.77 \pm 0.01$ & $0.16 \pm 0.02$ & 68 \\
\hline & 10 & $0.69 \pm 0.02$ & $0.39 \pm 0.02$ & $0.20 \pm 0.03$ & 68 \\
\hline & 25 & $0.68 \pm 0.02$ & $0.49 \pm 0.02$ & $0.15 \pm 0.02$ & 74 \\
\hline 773 & 2 & $0.55 \pm 0.01$ & $0.46 \pm 0.02$ & $0.31 \pm 0.03$ & 75 \\
\hline & 10 & $0.54 \pm 0.01$ & $0.48 \pm 0.02$ & $0.25 \pm 0.03$ & 74 \\
\hline & 25 & $0.56 \pm 0.01$ & $0.49 \pm 0.02$ & $0.15 \pm 0.01$ & 89 \\
\hline 873 & 2 & $0.23 \pm 0.01$ & $0.16 \pm 0.01$ & $0.13 \pm 0.01$ & 93 \\
\hline & 10 & $0.16 \pm 0.01$ & $0.50 \pm 0.02$ & $0.10 \pm 0.01$ & 93 \\
\hline & 25 & $0.16 \pm 0.01$ & $0.48 \pm 0.02$ & $0.12 \pm 0.01$ & \\
\hline
\end{tabular}

\subsection{Effects of $\mathrm{pH}$ and casein concentration}

The $\mathrm{pH}$ and casein concentration are two important parameters in the synthesis of mesoporous hydroxyapatite to achieve the desired porosity characteristics. For all of the solids, the specific surface area increased significantly at high $\mathrm{pH}$ and casein concentrations (see Supplementary material Figure SM-7). The surface area of HapCAS S.0 $_{\text {increased from }}$ 
54 to $84 \mathrm{~m}^{2} \mathrm{~g}^{-1}$ and 68 to $106 \mathrm{~m}^{2} \mathrm{~g}^{-1}$ when the solids were calcined at $573 \mathrm{~K}$ at a heating rate of $10 \mathrm{~K} \mathrm{~min}^{-1}$, and a $\mathrm{pH}$ of 7.0 to 11.0 , respectively.

The inflection points in the adsorption branches shifted to a higher pressure (i.e., lower inclination on the inflection point corresponds to capillary condensation) as the $\mathrm{pH}$ and casein concentration decreased. This result indicated that the solids synthesized at a higher $\mathrm{pH}$ and casein concentrations resulted in a more uniformed pore distribution, as shown in Figure 3. The curved slope in the capillary condensation region reflected the distribution of the pore size. In addition, a smoother slope suggests a heterogeneous pore size [61]. This behavior is observed because the casein micelles, which are stable, do not exhibit the same structure. Alterations in the temperature, $\mathrm{pH}$, ionic strength and high pressures lead to changes in the distribution of the casein micelle sizes [37].

At a pH of 7.0 (IP of casein is 4.8), the electrostatic repulsion between molecules decreased, and the hydrophobic interactions between molecules in the micelles increased. Therefore, the micellar structure becomes more compact, and the size of the micelles decreased. In addition, the micelles interacted strongly with each other [62]. This interaction affects the mass transfer between the solution and the substrate, which complicates the interaction between the ions (calcium and phosphate) and the casein micelles and affects the formation of the mesoporous structure.

At higher $\mathrm{pH}$ ( $\mathrm{pH} 11)$, the deprotonation of the carboxylic group of aspartic acid (Asp) and glutamic acid (Glu) residues altered the formation of casein micelles (i.e., electrostatic repulsion, destruction of salt bridges and formation of regions with isolated charges), which led to micelles with a larger radius [62].

The weak attraction between the casein molecules in the micelles at a higher $\mathrm{pH}$ promoted a weak attraction between the micellar structures, which favors mass transfer processes between the solution and the substrate and facilitated the interaction between the ions and casein to improve the formation of a mesoporous structure.

\subsection{Effect of not washing the solids.}

The TG curves for the synthesized hydroxyapatites before the washing and postsynthesis heat treatment (see Supplementary material Figure SM-8) indicated that the mass loss in the second step of the TG curve increased for solids synthesized at a higher $\mathrm{pH}$, suggesting the higher quantity of the organic groups on the solids obtained at a $\mathrm{pH}$ of 11 , as shown the CHN data (Supplementary material Table SM-3). 
The TG curves indicated that the three mass loss events due to the thermal decomposition of the inorganic skeleton remained nearly unchanged. However, some differences were observed. Based on comparison to the TG results for free casein (Figure SM-8), a second mass loss was observed between 498-870 K due to the decomposition of the casein in the pores of the solid. Table SM-3 shows the high mass losses for the solids obtained at a $\mathrm{pH}$ of 11 in the third and fourth mass loss events, which are associated with dehydroxylation of the hydroxyapatite.

These results were confirmed by the infrared spectra (see Supplementary material Figure SM-9) and CHN results discussed above. High intensity bands were detected at 2950$2850 \mathrm{~cm}^{-1}$ (Figure SM-9), and high CNH contents were detected.

\subsection{BSA sorption}

The BSA sorption was performed for mesoporous hydroxyapatites (i.e., the HapCAS $_{5.0 / 11.0}$ sample), and the same study was adopted for non-mesoporous as a reference.

The equilibrium times (Figure 4I) for BSA adsorption occurred at 20 and $40 \mathrm{~min}$ for the micro- and mesoporous samples with sorption capacities of 81 and $119 \mathrm{mg} \mathrm{g}^{-1}$, respectively. This behavior may be associated with higher surface areas and $\mathrm{OH}$ groups on the mesoporous sample.

Two plateaus were observed in the sorption isotherms, (Figure 4 II), for the monolayer formation, the mesoporous hydroxyapatite exhibited maximum BSA adsorption capacity of $125 \mathrm{mg} \mathrm{g}^{-1}$, which is higher than those obtained for pure hydroxyapatite (i.e., 81 $\mathrm{mg} \mathrm{g}^{-1}$ ). The second plateau did not reach an equilibrium and can be associated to multilayers of BSA linked through hydrogen and organophilic interactions.

The interaction of BSA and hydroxyapatites is based on the possibility of hydrogen bonding between the $-\mathrm{COO}^{-}$groups of the protein and the $\mathrm{P}-\mathrm{OH}$ on the hydroxyapatite surface [61]. The size of the BSA molecule is $10 \times 6 \mathrm{~nm}$, which is comparable to the pore diameter of mesoporous hydroxyapatite [63]. 

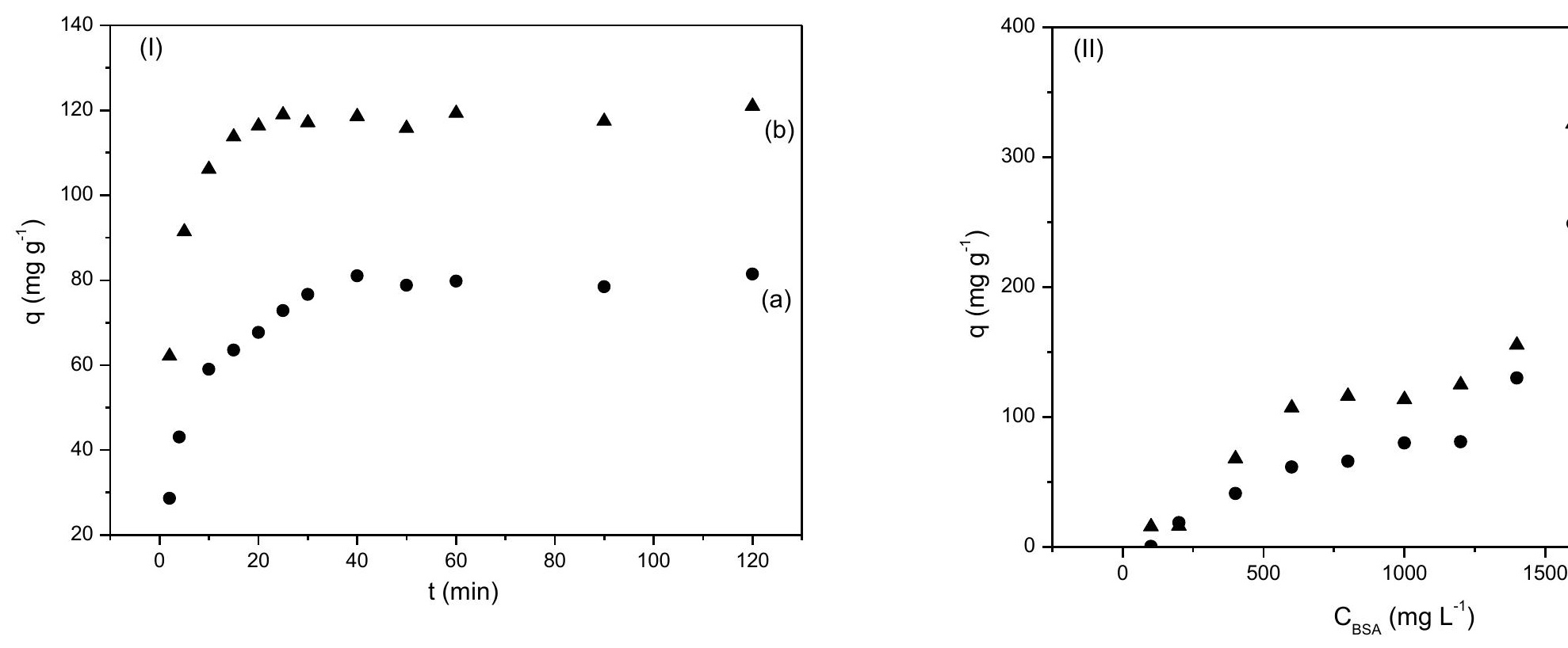

Figure 4. (I) Time and (II) concentration isotherms of the BSA adsorption on (a) microporous hydroxyapatites (b) mesoporous hydroxyapatite. $\mathrm{q}$ is the quantity of adsorbed protein, $\mathrm{C}_{\mathrm{BSA}}$ is the equilibrium concentration of protein and $\mathrm{t}$ is the time.

\section{Conclusion}

The synthesis of Hap in the presence of casein has been achieved. Different key parameters have been investigated including $\mathrm{pH}$, temperature and influence of washing and casein concentration to adjust the textural properties. The most appropriate acid-base conditions are approximately $\mathrm{pH} 11$, where casein is negatively charged. Interactions between the calcium, phosphate groups and the organic molecule are possible. The formation of casein micelles has been highlighted as already reported for this type of material. At high temperatures (in an oxygen atmosphere at $573 \mathrm{~K}$ and $10 \mathrm{~K} \mathrm{~min}^{-1}$ ), solids with larger mesopores and few micropores were obtained. 
The best casein concentration was approximately $5 \mathrm{mg} \mathrm{L}^{-1}$, and any excess amount does not interact with the inorganic part. Washing with water removed the excess unreacted casein and allow for the formation of a stable Hap.

In addition, the results indicated that casein is an excellent template for Hap solids because it can be extracted via a green process (washing with water) without the use of organic solvents or calcination.

The protein sorption capacity of the mesoporous Hap was important compared to other minerals, such as clay minerals [49]. Moreover, the obtained Hap can have importance for biomedical applications such as drug delivery agent for large molecules, considering its mesoporous structure.

\section{Acknowledgments}

Oberto Grangeiro da Silva was supported by a $\mathrm{PhD}$ grant from the CNPq. CETENE is acknowledged for the $\mathrm{N}_{2}$ adsorption/desorption measurements. $\mathrm{CNPq}$ is acknowledged for providing research fellowships to Maria Gardennia da Fonseca and Ieda Maria Garcia dos Santos and CAPES/COFECUB (835/15) for financial support.

There is no conflict of interest to declare.

\section{References}

[1] L.C. Palmer, C.J. Newcomb, S.R. Kaltz, E.D. Spoerke, S.I. Stupp, Biomimetic Systems for Hydroxyapatite Mineralization Inspired By Bone and Enamel, Chem Rev. 108 (2008) 4754-4783.

[2] M. Sadat-Shojai, M.-T. Khorasani, E. Dinpanah-Khoshdargi and A. Jamshidi, Synthesis methods for nanosized hydroxyapatite with diverse structures, Acta Biomater. 9 (2013) 7591-7621.

[3] R. Z. LeGeros, Calcium phosphate-based osteoinductive materials, Chem. Rev. 108 (2008) 4742-4753.

[4] B. Ben-Nissan, A.H. Choi, D.W. Green, B.A. Latella, J. Chou and A. Bendavid, Synthesis of Hydroxyapatite Nanocoatings by Sol-Gel Method for Clinical Applications, 
in S. Zhang (Ed.), Biological and Biomedical Coatings Handbook: Processing and Characterization, Vol. 1, CRC Press, Taylor and Francis Publishers, Boca Raton, 2011.

[5] J.C. Elliot, Structure and Chemistry of the Apatites and other Calcium Orthophosphates, Elsevier, Amsterdam, 1994.

[6] S.V. Dorozhkin and M. Epple, Biological and medical significance of calcium phosphates, Angew. Chem. Int. Ed. 41 (2002) 3130-3146.

[7] S.V. Dorozhkin, Calcium orthophosphates - Occurrence, properties, biomineralization, pathological calcification and biomimetic applications, Biomater. 1 (2011) 121-164.

[8] R.-B. Suena, S.-C. Lina and W.-H. Hsu, Hydroxyapatite-based immobilized metal affinity adsorbents for protein purification, J. Chromatogr. A 1048 (2004) 31-39.

[9] Z. Yang and C. Zhang, Adsorption/desorption behavior of protein on nanosized hydroxyapatite coatings: A quartz crystal microbalance study, Appl. Surf. Sci. 255 (2009) 4569-4574

[10] G. Pinto, S. Caira, G. Mamone, P. Ferranti, F. Addeo and G. Picariello, Fractionation of complex lipid mixtures by hydroxyapatite chromatography for lipidomic purposes, J. Chromatogr. A 1360 (2014) 82-92.

[11] P. Yang, Z. Quan, C. Li, X. Kang, H. Lian and J. Lin, Bioactive, luminescent and mesoporous europium-doped hydroxyapatite as a drug carrier, Biomater. 29 (2008) 43414347

[12] C. Santos, C. F. Rovath, R.-P. Franke, M. M. Almeida and M. E. V. Costa, Spray-dried hydroxyapatite-5-Fluorouracil granules as a chemotherapeutic delivery system, Ceram. Int. 35 (2009) 509-513.

[13] A. Sudo, M. Hasegawa, A. Fukuda and A. Uchida, Treatment of Infected Hip Arthroplasty with Antibiotic-Impregnated Calcium Hydroxyapatite, J. Arthroplasty (2008) 145-150.

[14] S. Leprêtre, F. Chai, J.-C. Hornez, G. Vermet, C. Neut, M. Descamps, H. F. Hildebrand and B. Martel, Prolonged local antibiotics delivery from hydroxyapatite functionalised with cyclodextrin polymers, Biomater. 30 (2009) 6086-6093.

[15] M.-P. Ginebra, C. Canal, M. Espanol, D. Pastorino and E.B. Montufar, Calcium phosphate cements as drug delivery materials, Adv. Drug Deliver. Rev. 64 (2012) 10901110 .

[16] T. Tsuchida, T. Yoshioka, S. Sakuma, T. Takeguchi and W. Ueda, Synthesis of Biogasoline from Ethanol over Hydroxyapatite Catalyst, Ind. Eng. Chem. Res. 47 (2008) 1443-1452. 
[17] D.C. Carvalho, L.G. Pinheiro, A. Campos, E.R.C. Millet, F.F. de Sousa, J.M. Filho, G.D. Saraiva, E.C. da Silva Filho, M.G. Fonseca and A.C. Oliveira, Characterization and catalytic performances of copper andcobalt-exchanged hydroxyapatite in glycerol conversion for1-hydroxyacetone production, Appl. Catal. A-Gen. 471 (2014) 39-49.

[18] O.G. da Silva, E.C. da Silva Filho, M.G. Fonseca, L.N.H. Arakaki and C. Airoldi, Hydroxyapatite organofunctionalized with silylating agents to heavy cation removal, J. Colloid Interf. Sci. 302 (2006) 485-491.

[19] Z. Zhang, M. Li, W. Chen, S. Zhu, N. Liu and L. Zhu, Immobilization of lead and cadmium from aqueous solution and contaminated sediment using nano-hydroxyapatite, Environ. Pollut. 158 (2010) 514-519.

[20] X.-Y. Zhao, Y.-J. Zhu, J. Zhao, B.-Q. Lu, F. Chen, C. Qi and J. Wu, Hydroxyapatite nanosheet-assembled microspheres: Hemoglobin-templated synthesis and adsorption for heavy metal ions, J. Colloid Interf. Sci. 416 (2014) 11-18.

[21] K.J.L. Burg, S. Porter and J.F. Kellam, Biomaterial developments for bone tissue engineering, Biomater. (2000) 2347-2359. [22] B. Wang, J.-J. Zhang, Z.-Y. Pan, X.-Q. Tao and H.-S. Wang, A novel hydrogen peroxide sensor based on the direct electron transfer of horseradish peroxidase immobilized on silica-hydroxyapatite hybrid film, Biosens. Bioelectron. 24 (2009) 1141-1145.

[23] A. Almirall, G. Larrecq, J.A. Delgado, S. Martınez , J.A. Planell and M.P. Ginebra, Fabrication of low temperature macroporous hydroxyapatite scaffolds by foaming and hydrolysis of an a-TCP paste A Biomater. 2004, 25, 3671-3680.

[24] N. Ikawa, H. Hori, T. Kimura, Y. Oumi and T. Sano, Templating Route for Mesostructured Calcium Phosphates with Carboxylic Acid- and Amine-Type Surfactants, Langmuir 24 (2008) 13113-13120.

[25] P.J.T. Reardon, J. Huang and J. Tang, Mesoporous calcium phosphate bionanomaterials with controlled morphology by an energy-efficient microwave method, J. Biomed. Mater. Res. A 103 A (2015) 3781-3789.

[26] J. Fan, J. Lei, C. Yu, B. Tu and D. Zhao, Hard-templating synthesis of a novel rod-like nanoporous calcium phosphate bioceramics and their capacity as antibiotic carriers, Mater. Chem. Phys. 103 (2007) 489-493.

[27] D. Li, X. Huang, Y. Wu, J. Li, W. Cheng, J. He, H. Tian and Y. Huang, Preparation of pH-responsive mesoporous hydroxyapatite nanoparticles for intracellular controlled release of an anticancer drug, Biomater. Sci. 4 (2016) 272-280. 
[28] S.M. Schmidt, J. McDonald, E.T. Pineda, A.M. Verwilst, Y. Chen, R. Josephs and A.E. Ostafin, Surfactant based assembly of mesoporous patterned calcium phosphate micronsized rods, Micropor. Mesopor. Mater. 94 (2006) 330-338.

[29] J. Zhang, M. Fujiwara, Q. Xu, Y. Zhu, M. Iwasa and D. Jiang, Synthesis of mesoporous calcium phosphate using hybrid templates, Micropor. Mesopor. Mater. 111 (2008) 411416.

[30] J. Yao, W. Tjandra, Y. Z. Chen, K. C. Tam, J. Mab and B. Soh, Hydroxyapatite nanostructure material derived using cationic surfactant as a template, J. Mater. Chem. 13 (2003) 3053-3057.

[31] B. Prélot and T. Zemb, Calcium phosphate precipitation in cationic templates, Mater. Sci. Eng. C 25 (2005) 553-559.

[32] N. Ikawa, H. Hori, T. Kimura, Y. Oumi and T. Sano, Unique surface property of surfactant -assisted mesoporous calcium phosphate, Micropor. Mesopor. Mater. 141 (2011) 56-60.

[33] Y.F. Zhao and J.Ma, Triblock co-polymer templating synthesis of mesostructured hydroxyapatite, Micropor. Mesopor. Mater. 87 (2005) 110-117.

[34] K. Lin, X. Liu, J. Chang and Y. Zhu, Facile synthesis of hydroxyapatite nanoparticles, nanowires and hollow nano-structured microspheres using similar structured hardprecursors, Nanoscale 3 (2011) 3052-3055.

[35] C.G. de Kruif and V.Y. Grinberg, Micellisation of $\alpha$-casein, Colloids Surf. A 210 (2002) 183-190.

[36] E.M. Little and C. Holt, An equilibrium thermodynamic model of the sequestration of calcium phosphate by casein phosphopeptides, Eur Biophys J. 33 (2004) 435-447.

[37] C. Broyard and F. Gaucheron, Modifications of structures and functions of caseins: a scientific and technological challenge, Dairy Sci. Technol. 95 (2015) 831-862.

[38] T.F. Kumosinski, J. Uknalis, P.H. Cooke and H.M. Farrell, Correlation of refined models for casein submicelles with electron microscopic studies of casein, LWT - Food Sci. Technol. 29 (1996) 326-333.

[39] P.D.S. Peixoto, A. Bouchoux, S. Huet, M.-N. Madec, D. Thomas, J. Floury and G. Gésan-Guiziou, Diffusion and partitioning of macromolecules in casein microgels: evidence for size-dependent attractive interactions in a dense protein system, Langmuir 31 (2015) 1755-1765.

[40] L.K. Creamer and A.R. Matheson, Action of alkali on casein, N.Z.J. Dairy Sci. Technol. 12 (1977) 253-259. 
[41] B. Yu, H. Bian and J. Plank, Self-assembly and characterization of Ca-Al-LDH nanohybrids containing casein proteins as guest anions, J. Phys. Chem. Solids 71 (2010) 468-472.

[42] M. Bachar, A. Mandelbaum, I. Portnaya, H. Perlstein, S. Even-Chen, Y. Barenholz and D. Danino, Development and characterization of a novel drug nanocarrier for oral delivery, based on self-assembled $\beta$-casein micelles, J. Control. Release 160 (2012)164171.

[43] S. Thachepan, M. Li and S. Mann, Mesoscale crystallization of calcium phosphate nanostructures in protein (casein) micelles, Nanoscale 2 (2010) 2400-2405.

[44] G.-J. Ding, Y.-J. Zhu, G.-F. Cheng, Y.-J. Ruan, C. Qi, T.-W. Sun, J. Wu and F. Chen, Hydrothermal synthesis of nanorod-assembled porous microspheres of hydroxyapatite/casein using ATP as a phosphorus source and casein sodium salt as a template Mater. Lett. 160 (2015) 242-245.

[45] A. Assifaoui, L. Huault, C. Maissiat, C. Roullier-Gall, P. Jeandet, J. Hirschinger, J. Raya, M. Jaber, J.-F. Lambert, P. Cayot, R.D. Gougeon and C. Loupiac, Structural studies of adsorbed protein (Betalactoglobulin) on natural clay (Montmorillonite), RSC Adv. 4 (2014) 61096-61103.

[46] S. Balme, R. Guégan, J.-M. Janot, M. Jaber, M. Lepoitevin, P. Dejardin, X. Bourratc and M. Motelica-Heino, Structure, orientation and stability of lysozyme confined in layered materials, Soft Matter. 9 (2013) 3188-3196.

[47] M. Bouchoucha, F. Tielens, F. Gaslain, F. C. Torro, S. Casale, A. Palcic, V. Valtchev, J.F. Lambert and M. Jaber, Melanin polymerization held in check: A composite of LDOPA with zeolite beta, J. Phys. Chem. C 119 (2015) 8736-8747.

[48] M. Jaber, T. Georgelin, H. Bazzi, F. Costa-Torro, J.-F. Lambert, G. Bolbach and G. Clodic, Selectivities in Adsorption and Peptidic Condensation in the (Arginine and Glutamic Acid)/Montmorillonite Clay System, J. Phys. Chem. C 118 (2014) 2544725455.

[49] M. Lepoitevin, M. Jaber, R. Guégan, J.-M. Janot, P. Dejardin, F. Henn and S. Balme, BSA and lysozyme adsorption on homoionic montmorillonite: Influence of the interlayer cation, Appl. Clay Sci. 95 (2014) 396-402.

[50] M.M. Bradford, A rapid and sensitive method for the quantitation of microgram quantities of protein utilizing the principle of protein-dye binding, Anal. Biochem. 72 (1976) 248-254. 
[51] M. Corno, A. Rimola, V. Bolis and P. Ugliengo, Hydroxyapatite as a key biomaterial: quantum-mechanical simulation of its surfaces in interaction with biomolecules, Phys. Chem. Chem. Phys. 12 (2010) 6309-6329.

[52] D. Li, Y. Zhu and Z. Liang, Alendronate hydroxyapatite functionalized mesoporous nanoparticles for drug deliver. Mater. Res. Bull. 48 (2013) 2201-2204.

[53] F. Zeng, J. Wang, Y. Wu, Y. Yu, W. Tang, M. Yin and C. Liu, Preparation of enlarged pore mesoporous hydroxyapatite via method of solubilizing gauxiliary model, Colloids Surf. A 441 (2014) 737-743.

[54] M. Uota, H. Arakawa, N. Kitamura, T. Yoshimura, J. Tanaka and T. Kijima, Synthesis of high surface area hydroxyapatite nanoparticles by mixed surfactant-mediated approach, Langmuir 21 (2005) 4724-4728.

[55] T. Georgelin, M. Jaber, T. Onfroy, A.-A. Hargrove, F. Costa-Torro and J.-F. Lambert, J. Phys. Chem. C, Inorganic phosphate and nucleotides on silica surface: condensation, dismutation, and phosphorylation, 117 (2013) 12579-12590.

[56] F. Tielens, G. Christel, G. Deroy, M. Jaber, L. Stievano, C.C. Diogo and J.-F. Lambert, Characterization of Phosphate Species on Hydrated Anatase $\mathrm{TiO}_{2}$ Surfaces, Langmuir 32 (2016) 997-1008.

[57] D. Lin-Vien, N. Colthup, W. Fateley and J. Grasselli, The Handbook of Infrared and Raman Characteristic Frequencies of Organic Molecules, Academic Press, San Diego, 1991.

[58] B. Purevsuren and Y. Davaajav, Thermal analysis of casein, J. Therm. Anal. Calorim. 65 (2001) 147-152.

[59] B. Locardi, U.E. Pazzaglia, C. Gabbi and B. Profilo, Thermal behaviour of hydroxyapatite intended for medical applications, Biomater. 14 (1993) 437-441.

[60] E. Adolfsson, M. Nygren and L. Hermansson, Decomposition Mechanisms in Aluminum Oxide-Apatite Systems, J. Am. Ceram. Soc. 82 (1999) 2909-2912.

[61] M. Kruk, M. Jaroniec and A. Sayari, Relations between pore structure parameters and their implications for characterization of MCM-41 using gas adsorption and X-ray diffraction Chem. Mater. 11 (1999) 492-500.

[62] Y. Liu and R. Guo, The interaction between casein micelles and gold nanoparticles, J. Colloid Interf. Sci. 332 (2009) 265-269.

[63] M. Manzano, V. Aina, C. O. Arean, F. Balas, V. Cauda, M. Colilla, M. R. Delgado and M. Vallet-Regí, Studies on MCM-41 mesoporous silica for drug delivery: Effect of particle morphology and amine functionalization, Chem. Eng. J. 137 (2008) 30-37. 


\section{Supplementary material}

Figure SM-1. XRD patterns of the (a) washed and non-calcined hydroxyapatite HapCAS1.0/7.0

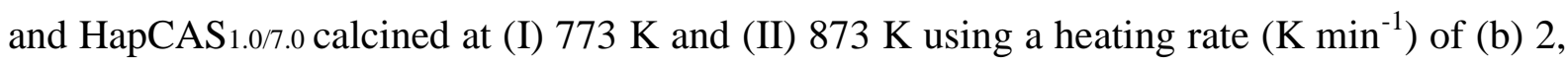
(c) 10 and (d) 25 .

Figure SM-2. Nitrogen adsorption/desorption isotherms of $\operatorname{HapCAS}_{1.0 / 7.0}$ calcined at a heating rate $\left(\mathrm{K} \mathrm{min}^{-1}\right)$ of (a) 2, (b) 10 and (c) 25 and temperatures (K) of $573(\mathbf{\square}), 773(\Delta)$ and 873 (o).

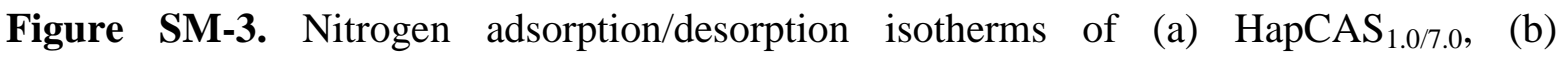
HapCAS $_{1.0 / 8.0}$, (c) HapCAS $\mathrm{H}_{1.0 / 11.0}$, calcined at $573 \mathrm{~K}$ with a heating rate of $10 \mathrm{~K} \mathrm{~min}^{-1}(\Delta)$. Non-calcined sample (ם).

Figure SM-4. Infrared spectra of HapCAS ${ }_{1.0 / 7.0}$ for the non-calcined (a) and calcined samples at temperatures of (b) 873 , (c) 773 and (d) $573 \mathrm{~K}$ with a heating rate of (I) 2, (II) 10 and (II) $25 \mathrm{~K} \mathrm{~min}^{-1}$.

Figure SM-5. Thermogravimetric curves of HapCAS $\mathrm{H}_{1.0 / 7.0}$ obtained before (a) and after calcination at temperatures (K) of (b) 573 , (c) 773 and (d) $887 \mathrm{~K}$ with a heating rate (K min $^{-}$ ${ }^{1}$ ) of (I) 2, (II) 10 and (II) 25.

Figure SM-6. TG/DTG curve for casein.

Figure SM-7. Influence of the $\mathrm{pH}$ and casein concentration on the specific surface area (S) of HAP synthesized with a casein concentration of $1 \mathrm{mg} \mathrm{mL}^{-1}(\boldsymbol{\bullet})$ and $5 \mathrm{mg} \mathrm{mL}^{-1}(\bullet)$ and calcined at $573 \mathrm{~K}$ with a heating rate of $10 \mathrm{~K} \mathrm{~min}^{-1}$.

Figure SM-8. TG curves for unwashed Hap synthesized with a casein concentration of (I) 1 $\mathrm{mg} \mathrm{L}^{-1}$ and (II) $5 \mathrm{mg} \mathrm{L}^{-1}$ at a pH of (a) 11.0, (b) 8.0 and (c) 7.0.

Figure SM-9. Infrared spectra of unwashed Hap synthesized with a casein concentration $\left(\mathrm{mg} \mathrm{L}^{-1}\right)$ of (I) 1 and (II) 5 at a pH of (a) 11.0, (b) 8.0 and (c) 7.0.

Table SM-1. Mass loss percentages obtained from TG/DTG curves for HAPCAS 1.0/7.0 $_{\text {after }}$ thermal treatment (*washed and non-calcined sample).

Table SM-2. Mass loss data based on thermogravimetry for hydroxyapatites prior to washing and thermal treatment.

Table SM-3. CHN data for the HAP synthesized at different $\mathrm{pH}$ values and casein concentrations prior to washing. 